\title{
Purification and characterization of alkaline endo-1,4- $\beta$-glucanases from alkalophilic Bacillus sp. KSM-635
}

\author{
Tadashi Yoshimatsu, Katsuya Ozaki, Shitsuw Shikata, Yu-ichi Ohta, Kenzo Koike, \\ SHuJI KaWAi and Susumu Ito*
}

Tochigi Research Laboratories of Kao Corporation, 2606 Akabane, Ichikai, Tochigi 321-34, Japan

(Received 30 April 1990; revised 22 June 1990; accepted 27 June 1990)

\begin{abstract}
Two carboxymethylcellulases (CMCase, 1,4- $\beta$-D-glucan glucanohydrolase, EC 3.2.1.4), designated E-H and E-L, were purified to homogeneity from a culture filtrate of the alkalophilic Bacillus sp. KSM-635, by chromatography on DEAE-Toyopearl 650S and gel filtration on Bio-Gel A-0.5m. The purified CMCases both contained approximately $2-3 \%(\mathrm{w} / \mathrm{w})$ glucosamine. Molecular masses deduced from SDS-PAGE were $130 \mathrm{kDa}$ for E-H and $103 \mathrm{kDa}$ for E-L. The pH optima of the enzymes were both about 9.5 , and their optimum temperatures were around $40{ }^{\circ} \mathrm{C}$. Activities of both enzymes were inhibited by $\mathrm{Hg}^{2+}, \mathrm{Cu}^{2+}, \mathrm{Fe}^{2+}$ and $\mathrm{Fe}^{3+}$, but sulphydryl inhibitors, such as $\boldsymbol{N}$-ethylmaleimide, monoiodoacetate and 4-chloromercuribenzoate, had either no effect or a slightly inhibitory effect. $\boldsymbol{N}$-Bromosuccinimide was strongly inhibitory, suggesting that a tryptophan residue is essential for the activity of the CMCases from Bacillus. In addition, the activities of both E-H and E-L were stimulated by $\mathrm{Co}^{2+}$, and they required $\mathrm{Mg}^{2+}, \mathrm{Ca}^{2+}, \mathrm{Mn}^{2+}$ or $\mathrm{Co}^{2+}$ for stabilization. Both enzymes efficiently hydrolysed carboxymethylcellulose ( $\beta$-1,4-linkage) and lichenan $(\beta-1,3 ; 1,4$-linkage), but crystalline cellulosic substrates, curdlan ( $\beta$-1,3-linkage), laminarin $(\beta$-1,3; 1,6-linkage) and 4-nitrophenyl- $\beta$-D-glucopyranoside were hydrolysed very little, if at all. 4-Nitrophenyl- $\beta$-D-cellobioside was hydrolysed by both enzymes to liberate 4-nitrophenol, and their hydrolysis rates were higher at neutral pH than at alkaline pH.
\end{abstract}

\section{Introduction}

The industrial application of cellulases has been recognized mainly in terms of their potential for use in the saccharification of cellulosic materials, and much attention has been focused on Trichoderma (e.g. Mandels, 1982; Berghem et al., 1976; Beldman et al., 1985) and other cellulolytic fungi (Kubo \& Nisizawa, 1983; Rao et al., 1986). Several bacteria have also been studied for their ability to produce cellulolytic enzymes, and these bacteria include Clostridium (Ng \& Zeikus, 1981; Creuzet et al., 1983), Cellulomonas (Nakamura \& Kitamura, 1983), Ruminococcus (Halliwell \& Bryant, 1963; Gardner et al., 1987) and Cytophaga (Chang \& Thayer, 1977). Most of the information on the properties of cellulases and the mechanisms of their activity has come from studies of cellulases from these organisms. Many authors have also reported that members of the

\footnotetext{
Abbreviations: CMC, carboxymethylcellulose; CMCase, carboxymethylcellulase; NPC, 4-nitrophenyl $\beta$-D-cellobioside; NPG, 4-nitrophenyl $\beta$-D-glucopyranoside.
}

genus Bacillus produce cellulases and hemicellulases in culture (Fogarty et al., 1974; Priest, 1977), but to date, little is known about the production and the properties of Bacillus enzymes that hydrolyse carboxymethylcellulose (CMC) (Tewari \& Chahal, 1977; Horikoshi et al., 1984; Dhillon et al., 1985; Chan \& Au, 1987), and most of these enzymes are not capable of hydrolysing crystalline forms of cellulose.

Recently, we isolated several strains of Bacillus that produce alkaline carboxymethylcellulases (CMCase, EC 3.2.1.4), the properties of which fulfil the essential requirements for enzymes to be used in laundry detergents (Kawai et al., 1988; Ito et al., 1989; Shikata et al., 1990). In this report, we describe a detailed study of alkaline CMCases from one of the isolates, alkalophilic Bacillus sp. KSM-635 (Ito et al., 1989). This study was undertaken not only to enhance our immediate understanding of such enzymes, but also to provide a foundation for future investigations of the structure, mechanism of action and biosynthesis of the enzymes. For these purposes, we purified and characterized the alkaline CMCases found in cultures of Bacillus $\mathrm{sp}$. KSM-635. 


\section{Methods}

Organism. The organism used was Bacillus sp. KSM-635. A mutant form of this organism is currently used for the industrial production of an alkaline CMCase which serves as an effective additive in laundry detergents (Ito et al., 1989).

Enzyme assays. Cellulase activity was routinely assayed by measuring the rate of formation of reducing sugars from CMC (A01MC; degree of substitution 0.68; Sanyo Kokusaku Pulp) as a substrate, in $0.1 \mathrm{M}$-glycine/ $\mathrm{NaOH}$ (pH 9.5) as the reaction buffer (Ito et al., 1989). The reducing sugars liberated from $\mathrm{CMC}$ were quantified as glucose by the 3,5-dinitrosalicylic acid procedure (Miller et al., 1960). Assays for cellulolytic activity against filter paper, Avicel, swollen celluloses, cellobiose, lichenan (from Cetralia islandica, Sigma), curdlan (from Alcaligenes faecalis var. mixogenes, Wako Pure Chemical), laminarin (from Laminaria digitata, Sigma), 4-nitrophenyl $\beta$-D-glucopyranoside (NPG, Sigma), and 4-nitrophenyl $\beta$-D-cellobioside (NPC, Sigma) were performed according to published procedures (Kawai et al., 1988; Ito et al., 1989). The value of each enzymic activity reported is the mean of three or more experiments. Protein was determined by the procedure of Bradford (1976) with bovine plasma albumin as protein standard and a Bio-Rad protein assay kit (Bio-Rad). One unit (U) of enzyme activity was defined as the amount of protein that produces $1.0 \mu \mathrm{mol}$ of product $\min ^{-1}$ under the standard assay conditions.

Electrophoretic analysis. PAGE was performed on $12 \%(\mathrm{w} / \mathrm{v})$ polyacrylamide slab gels $(70 \mathrm{~mm} \times 80 \mathrm{~mm}, 1 \mathrm{~mm}$ thickness $)$ by the method of Davis (1964) with $5 \mathrm{~mm}$-Tris/38 mM-glycine (pH 8.3) as the running buffer. SDS-PAGE was also carried out on slab gels (Laemmli, 1970) after the enzyme preparation had been heated at $95^{\circ} \mathrm{C}$ for $5 \mathrm{~min}$ in $62.5 \mathrm{mM}$-Tris/ $\mathrm{HCl}$ buffer (pH 6.8) that contained (w/v) $2 \% \mathrm{SDS} / 10 \%$ glycerol $/ 5 \% 2$-mercaptoethanol. The running buffer used was $25 \mathrm{mM}$ Tris/glycine buffer $(\mathrm{pH} 8 \cdot 3)$ that contained $0 \cdot 1 \%(\mathrm{w} / \mathrm{v})$ SDS. Proteins were visualized by silver staining (Oakley et al., 1980).

Active staining of CMCase activity with Congo red dye. Protein bands associated with CMCase activity were visualized by staining with Congo red after PAGE, by laying the slab gels at $30^{\circ} \mathrm{C}$ for $30 \mathrm{~min}$ on top of a CMC-agar sheet, essentially according to the method of Béguin (1983). The CMC-agar sheet ( $5 \mathrm{~mm}$ thickness) was composed of $2 \%$ (w/v) CMC, $3 \%(\mathrm{w} / \mathrm{v}) \mathrm{NaCl}, 0.1 \mathrm{M}$-glycine/NaOH buffer (pH 9) and $0.8 \%(\mathrm{w} / \mathrm{v})$ agar (Difco). This sheet was stained with $0.1 \%(\mathrm{w} / \mathrm{v})$ Congo red solution for $15 \mathrm{~min}$ and then destained for $15 \mathrm{~min}$ in $1.0 \mathrm{M}-\mathrm{NaCl}$ solution, at room temperature. The protein bands with CMCase activity were located as clear zones on the sheet of red background.

Preparation of cultures. Bacillus sp. KSM-635 was grown in a medium that contained $(\mathrm{w} / \mathrm{v}): 1.5 \%$ meat extract (Lab-Lemco powder, Oxoid), $0.4 \%$ yeast extract (Difco), $1.5 \%$ sucrose, $0.07 \% \quad \mathrm{Na}_{2} \mathrm{SO}_{4}$, $0.015 \% \mathrm{CaCl}_{2} .2 \mathrm{H}_{2} \mathrm{O}$ and $0.5 \% \mathrm{Na}_{2} \mathrm{CO}_{3}$. Calcium chloride and $\mathrm{Na}_{2} \mathrm{CO}_{3}$ were autoclaved separately. The organism was cultivated with shaking at $30^{\circ} \mathrm{C}$ for $2 \mathrm{~d}$ in $50 \mathrm{ml}$ aliquots of medium in $500 \mathrm{ml}$ flasks. Cells were removed by centrifugation, and the supernatant obtained was used as the cell-free culture medium.

Purification of two forms of alkaline CMCase. Purification was done at $4{ }^{\circ} \mathrm{C}$. The cell-free supernatant from a 31 culture was concentrated by ultrafiltration on a PM-10 membrane (10 kDa cutoff, Amicon) and then dialysed overnight against $10 \mathrm{~mm}$-Tris/ $\mathrm{HCl}$ buffer $(\mathrm{pH} 7.5)$ containing $5 \mathrm{~mm}-\mathrm{CaCl}_{2}$ (buffer $\mathrm{A}$ ). The dialysate was applied to a column of DEAE-Toyopearl $650 \mathrm{~S}(4.4 \mathrm{~cm} \times 40 \mathrm{~cm}$; Tosoh) equilibrated with buffer $A$ containing $0.2 \mathrm{M}-\mathrm{NaCl}$. The adsorbed materials were eluted with a 61 linear gradient of 0.2 to $0.4 \mathrm{M}-\mathrm{NaCl}$ in the equilibrating buffer; $10 \mathrm{ml}$ fractions were collected at a flow rate of $40 \mathrm{ml} \mathrm{h}^{-1}$. The fractions corresponding to the peak of CMCase activity were eluted at $250 \mathrm{~mm}-\mathrm{NaCl}$. The active fractions (tubes nos 480-560) were combined, and then concentrated by ultrafiltration (PM membrane). The concentrate was divided into portions, and each portion was chromatographed sequentially on a column of Bio-Gel A-0.5m $(2.5 \mathrm{~cm} \times 90 \mathrm{~cm}$; Bio-Rad) equilibrated with buffer $A$ containing $0 \cdot 1 \mathrm{M}-\mathrm{NaCl}$. Elution was carried out with the equilibrating buffer at a flow rate of $20 \mathrm{ml} \mathrm{h}^{-1}$. Fraction size was $4 \mathrm{ml}$. In some of these fractions, CMCase activity was checked by both protein and activity staining after nondenaturing PAGE. Two peaks of CMCase activity were eluted from the Bio-Gel A-0.5m column and the active fractions with high specific activity (tubes nos 60-70 and 74-80) were pooled separately and used as the final preparations of the enzymes.

Determination of molecular masses. Molecular masses were estimated by gel filtration on a column of Bio-Gel A-1.5m $(1.5 \mathrm{~cm} \times 70 \mathrm{~cm}$; BioRad) with buffer $A$ containing $0.1 \mathrm{M}-\mathrm{NaCl}$ as the equilibrating and elution buffer. The eluate was collected in $1 \mathrm{ml}$ fractions at a flow rate of $4.4 \mathrm{ml} \mathrm{h}^{-1}$. The purified enzymes and marker proteins were chromatographed separately on the defined column. The molecular mass markers (Pharmacia) contained the following proteins (molecular masses are given in $\mathrm{Da})$; bovine thyroglobulin $(669000)$; horse spleen ferritin (440000); bovine liver catalase (232000); rabbit muscle aldolase (158000); bovine serum albumin (67000); hen egg ovalbumin (43000); bovine pancreas chymotrypsinogen A (25000). Molecular masses were also determined by SDS-PAGE under the conditions described above on $12 \%$ polyacrylamide slab gels. The marker proteins (Bio-Rad), were as follows (molecular masses in Da): rabbit skeletal muscle myosin (200000); Escherichia coli $\beta$-galactosidase (116250); rabbit muscle phosphorylase $b(97400)$; bovine serum albumin (66200); hen egg white ovalbumin (42699); bovine carbonic anhydrase (31000); soybean trypsin inhibitor (21500).

Chromatographic analysis of the products of hydrolysis of cellooligosaccharides. Excess purified enzyme $(30 \mathrm{mU})$ was incubated with $0.5 \mathrm{mg}$ cello-oligosaccharide, namely, cellobiose (G2) through cellohexaose (G6) (Seikagaku Kogyo), at $30^{\circ} \mathrm{C}$ for $12 \mathrm{~h}$ in $50 \mathrm{~mm}$-pyrophosphate buffer ( $\mathrm{pH} 9.0$ ). The reactions were stopped by the addition of ethanol. The products of hydrolysis were analysed by ascending chromatography on Whatman no. 1 filter paper, in a solvent system of $n$-butanol/pyridine/water ( $6: 4: 3$, by vol.). After one to four ascents of solvent at room temperature, the chromatogram was developed by an alkaline acetone/silver nitrate dip procedure (Trevelyan et al., 1950).

Determination of carbohydrate. Each purified enzyme was hydrolysed by treatment with $2 \cdot 2 \mathrm{M}$-trifluoroacetic acid at $100^{\circ} \mathrm{C}$ for $7 \mathrm{~h}$, reduced by $\mathrm{NaBH}_{4}$ and then treated with anhydrous acetic acid at $100{ }^{\circ} \mathrm{C}$ for $30 \mathrm{~min}$, according to the alditol-acetate procedure (Björndal et al., 1970). Gas-chromatographic determination of sugar alcohols in the preparations was carried out at $200^{\circ} \mathrm{C}$ with $\mathrm{He}$ as the flow gas $\left(60 \mathrm{ml} \mathrm{min}{ }^{-1}\right)$, a $3 \%(w / v)$ ECNSS-M column (4 mm $\times 2 \mathrm{~m}$; Gasukuro $\mathrm{Kogyo}$ ) and a flame-ionization detector $\left(300^{\circ} \mathrm{C}\right)$. The carbohydrate (as glucosamine) was also estimated by the phenol/sulphuric acid procedure (Hodge et al., 1962) and by the Morgan-Elson procedure (Levvy \& McAllan, 1959).

Divalent cation assays. Each preparation of enzyme $(4 \mathrm{ml})$ was treated with $10 \mathrm{~mm}$-EDTA and $10 \mathrm{~mm}$-EGTA at $5{ }^{\circ} \mathrm{C}$ for $12 \mathrm{~h}$ prior to the assay. The treated solution was diluted to $40 \mathrm{ml}$ by addition of $20 \mathrm{~mm}$ glycine/ $\mathrm{NaOH}$ buffer ( $\mathrm{pH} 9.0$ ), and then concentrated to $2 \mathrm{ml}$ in a centrifuge tube concentrator (Centricon-10, Amicon). A divalent cation was added at a final concentration of $5 \mathrm{mM}$ to the concentrate, and the mixture was dialysed at $5^{\circ} \mathrm{C}$ for $12 \mathrm{~h}$ against 500 vol $20 \mathrm{~mm}$ glycine/ $\mathrm{NaOH}$ buffer ( $\mathrm{pH} 9 \cdot 0$ ) containing the divalent cation at $5 \mathrm{mM}$. 
Table 1. Purification of the CMCases from Bacillus sp. KSM-635

\begin{tabular}{lccccc}
\hline \hline \multicolumn{1}{c}{$\begin{array}{c}\text { Purification } \\
\text { step }\end{array}$} & $\begin{array}{c}\text { Total } \\
\text { protein } \\
(\mathrm{mg})\end{array}$ & $\begin{array}{c}\text { Total } \\
\text { activity } \\
(\mathrm{U})\end{array}$ & $\begin{array}{c}\text { Specific } \\
\text { activity } \\
\left(\mathrm{U} \mathrm{mg}^{-1}\right)\end{array}$ & $\begin{array}{c}\text { Yield } \\
(\%)\end{array}$ & $\begin{array}{c}\text { Purification } \\
\text { (-fold) }\end{array}$ \\
\hline $\begin{array}{l}\text { Cell-free culture } \\
\text { DEAE-Toyopearl 650S }\end{array}$ & 1224 & 19833 & $16 \cdot 2$ & 100 & $1 \cdot 0$ \\
$\begin{array}{l}\text { Bio-Gel A-0.5m } \\
\text { E-H }\end{array}$ & 395 & 15889 & $40 \cdot 2$ & 80 & $2 \cdot 5$ \\
E-L & 327 & 11061 & $33 \cdot 8$ & 56 & $(2 \cdot 1)$ \\
\hline \hline
\end{tabular}

\section{Results}

\section{Purification}

In order to obtain a high yield of purified CMCase, the cell-free supernatant of a culture of Bacillus sp. KSM-635 was fractionated directly on a column of DEAEToyopearl $650 \mathrm{~S}$, immediately after dialysis. The subsequent gel filtration on Bio-Gel A-0.5m separated the CMCase activity of the eluate into two fractions, designated E-H and E-L. The first peak of activity $(E-H)$ contained $70 \%$ of the total amount of CMCase applied to the column. Specific activities against CMC substrate were $34 \mathrm{U}$ (mg protein) ${ }^{-1}$ for $\mathrm{E}-\mathrm{H}$ and $59 \mathrm{U}(\mathrm{mg}$ protein $)^{-1}$ for E-L. When $\mathrm{Ca}^{2+}$ was omitted from buffer $A$, it was difficult to purify and separate these enzymes and there was an appreciable loss of activity. The degree of purification and total recovery were $2 \cdot 1$-fold and $56 \%$ for $\mathrm{E}-\mathrm{H}$, and 3.7 -fold and $12 \%$ for $\mathrm{E}-\mathrm{L}$, as summarized in Table 1 . A very high overall yield of CMCase activity was achieved $(68 \%$ of the initial activity).

\section{Homogeneity and absorption spectra}

The preparations of purified enzymes, E-H and E-L, were homogeneous, as judged by nondenaturing PAGE and SDS-PAGE. Each band of protein, detected by staining after nondenaturing PAGE, coincided fairly well with the single band visualized by active staining with Congo red. The purified enzymes had absorption maxima at $280 \mathrm{~nm}$ in $10 \mathrm{mM}$-phosphate buffer $(\mathrm{pH} 7 \cdot 2)$. In addition to absorption at $280 \mathrm{~nm}$ due to simple protein, the spectra of both enzymes had a shoulder at $290 \mathrm{~nm}$, possibly attributable to absorption by tryptophan residues in the enzyme molecules (Clarke, 1987).

\section{Molecular masses and isoelectric points.}

The molecular masses of E-H and E-L were estimated to be $500 \mathrm{kDa}$ and $100 \mathrm{kDa}$, respectively, by gel-filtration chromatography on a column of Bio-Gel A-1.5m. SDSPAGE gave molecular masses for E-H and E-L of
$130 \mathrm{kDa}$ and $103 \mathrm{kDa}$, respectively. These results indicate that E-H exists as a tetramer and that E-L has a monomeric structure. Gel focusing of the enzymes gave isoelectric points for E-H and E-L of less than $\mathrm{pH} 4$ in both cases, as estimated by the method of Wrigley (1971).

\section{Carbohydrate in the enzymes}

E-H and E-L both contained carbohydrate. They reacted positively with the Morgan-Elson reagent, indicating that the carbohydrate was an amino sugar. In order to identify the carbohydrate moiety of each enzyme, the carbohydrate was reduced by $\mathrm{NaBH}_{4}$, acetylated and then analysed by gas chromatography on an ECNSS-M column. A main peak corresponding to glucosaminitol tetra-acetate was detected in the case of both enzymes, with the same retention time as an authentic sample and the carbohydrate in E-H and E-L was thus identified as glucosamine. Both enzymes contained approximately $2-3 \%(w / w)$ glucosamine. The nature of the intramolecular glucosidic linkage of the amino sugar was not determined.

\section{Effects of chemical reagents}

The effect of divalent cations on E-H and E-L was examined by first treating the enzymes with EDTA and EGTA to remove any endogenous divalent cations, and then adding various divalent cations to the reaction mixture (see Methods). $\mathrm{Co}^{2+}(5 \mathrm{~mm})$ stimulated the CMCase activities of both enzymes 1.3-fold, but the other divalent cations $\left(\mathrm{Ca}^{2+}, \mathrm{Mg}^{2+}\right.$ and $\left.\mathrm{Mn}^{2+}\right)$ had either no effect or slightly stimulatory effects.

When the native preparations of E-H and E-L were incubated with various cations and chemicals $(1 \mathrm{mM})$ for $20 \mathrm{~min}$ at $30^{\circ} \mathrm{C}$ and $\mathrm{pH} 9.5$ in $0.1 \mathrm{M}$-glycine $/ \mathrm{NaOH}$ buffer, $\mathrm{Hg}^{2+}, \mathrm{Cu}^{2+}, \mathrm{Pb}^{2+}, \mathrm{Fe}^{2+}$ and $\mathrm{Fe}^{3+}$ inhibited the activities of both enzymes by $30-50 \%$, but other sulphydryl inhibitors, such as $N$-ethylmaleimide, monoiodoacetate and 4-chloromercuribenzoate $(1 \mathrm{mM})$ either had no effect or caused moderate levels of 

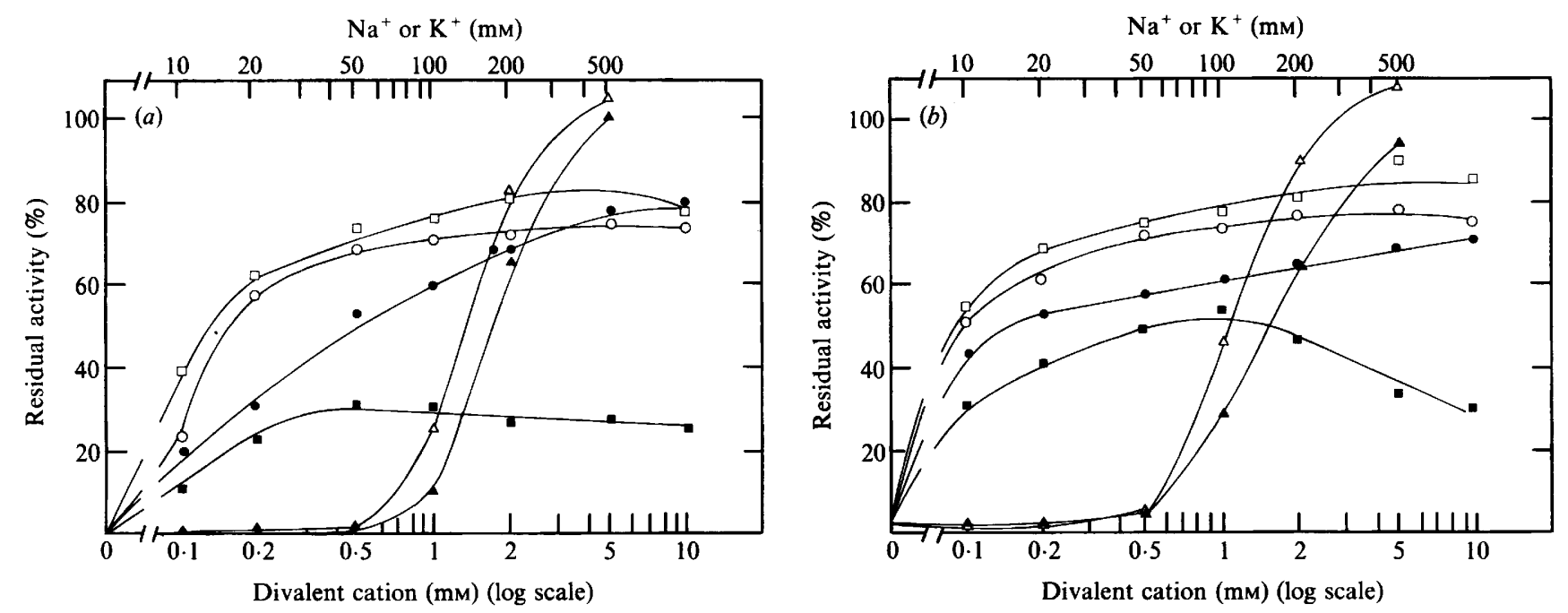

Fig. 1. Protective effects of some cations on the thermal stability of the purified CMCases. Enzyme $(0.33 \mathrm{U})$ was preheated at $45^{\circ} \mathrm{C}$ for $10 \mathrm{~min}$ in $0.1 \mathrm{M}$-glycine/ $\mathrm{NaOH}$ buffer $(\mathrm{pH} 9.5)$ in the presence of the indicated cations at various concentrations. $\mathrm{O}, \mathrm{Ca}^{2+} ; \mathbf{O}, \mathrm{Mg}^{2+} ; \square$, $\mathrm{Mn}^{2+} ; \mathbf{\square}, \mathrm{Co}^{2+} ; \triangle, \mathrm{Na}^{+} ; \boldsymbol{\Lambda}, \mathrm{K}^{+}$. After the heat treatment, samples were immediately cooled in an iced-water bath and aliquots $(0 \cdot 1 \mathrm{ml})$ were used to determine the residual activities of E-H $(a)$ or E-L $(b)$ at $40^{\circ} \mathrm{C}$ in $0.1 \mathrm{M}$-glycine/ $\mathrm{NaOH}$ buffer (pH 9.5). The residual activities of both enzymes without additives were nearly zero, and the control activities (without heating) were taken as $100 \%$.

inhibition. Under the same assay conditions, $\mathrm{Co}^{2+}$ stimulated the activities of both enzymes approximately 1.3-fold, but $\mathrm{Ca}^{2+}, \mathrm{Mg}^{2+}$ and $\mathrm{Mn}^{2+}$ had no effect. $\mathrm{N}$ Bromosuccinimide $(10 \mu \mathrm{M})$ completely abolished the activities of E-H and E-L at $\mathrm{pH} 6.0$ in $50 \mathrm{~mm}$-acetate buffer. The following reagents (1 mM each) were without effect on the activity of the Bacillus enzymes under our assay conditions at alkaline $\mathrm{pH}$; di-isopropyl-phosphofluoridate, phenylmethanesulphonyl fluoride and sodium azide.

\section{Effect of temperature and $\mathrm{pH}$ on the activity and stability of each enzyme}

The optimum temperatures for reactions were examined. The two CMCases exhibited a similar temperatureactivity profile, the optimum temperature being around $40{ }^{\circ} \mathrm{C}$ in $0.1 \mathrm{M}$-glycine/ $\mathrm{NaOH}$ buffer (pH 9.5). Thermal stabilities of E-H and E-L were assessed in $0.1 \mathrm{M}-$ glycine/ $\mathrm{NaOH}$ buffer (pH 9.5) after heating for $10 \mathrm{~min}$ at various temperatures. Both enzymes were stable up to $.35^{\circ} \mathrm{C}$. Complete loss of enzyme activity was observed after heating to $45^{\circ} \mathrm{C}$ in each case. When $\mathrm{Ca}^{2+}$ was present, the inactivation temperatures shifted from $45^{\circ} \mathrm{C}$ to $50^{\circ} \mathrm{C}$ for $\mathrm{E}-\mathrm{H}$ and from $45^{\circ} \mathrm{C}$ to $55^{\circ} \mathrm{C}$ for E-L. Several inorganic ions also protected the two enzymes from inactivation at $45^{\circ} \mathrm{C}$, as shown in Fig. 1. The presence of $\mathrm{Mg}^{2+}, \mathrm{Mn}^{2+}$ and $\mathrm{Ca}^{2+}$ (at more than $0.1 \mathrm{mM}$ ) markedly reduced the heat inactivation of the enzymes. $\mathrm{Co}^{2+}$ ions were somewhat less effective than these three ions. $\mathrm{Na}^{+}$and $\mathrm{K}^{+}$(at more than $0.2 \mathrm{M}$ ) effectively protected the CMCases from thermal inactivation at $45^{\circ} \mathrm{C}$.

The effect of $\mathrm{pH}$ on the activities of E-H and E-L was determined at $40{ }^{\circ} \mathrm{C}$ in various buffers ranging from $\mathrm{pH} 3$ to $\mathrm{pH}$ 13. Both enzymes hydrolysed CMC and were active over a wide range from $\mathrm{pH} 6$ to $\mathrm{pH} 12.5$, the maximum activities being observed at $\mathrm{pH} 9.5$ in both cases in $0.1 \mathrm{M}$-glycine/ $\mathrm{NaOH}$ buffer. To determine the stability of enzyme activities with changes in $\mathrm{pH}, \mathrm{E}-\mathrm{H}$ and $\mathrm{E}-\mathrm{L}$ were preincubated at $5^{\circ} \mathrm{C}$ for $3 \mathrm{~h}$ in various buffers and then assayed at $\mathrm{pH} 9 \cdot 5$ and $40^{\circ} \mathrm{C}$. Both enzymes were very stable to incubation over a range between pH 6 and pH 11. The enzyme activity was completely lost when either enzyme was incubated at $\mathrm{pH} 4.5$ or $\mathrm{pH} 12$ under these conditions.

\section{Substrate specificity}

The purified enzymes were tested for their ability to hydrolyse various carbohydrates and aryl-glucosides at $30^{\circ} \mathrm{C}$ and at $\mathrm{pH} 9.5$ or $\mathrm{pH} \mathrm{7.0} \mathrm{(Table} \mathrm{2).} \mathrm{Of} \mathrm{the}$ carbohydrate substrates tested, $\mathrm{CMC}(\beta-1,4$-linkage $)$ and lichenan $(\beta-1,3 ; 1,4$-linkage) were efficiently hydrolysed by E-H and E-L at pH 9.5 in $0.1 \mathrm{M}$-glycine/ $\mathrm{NaOH}$ buffer. The rates of hydrolysis by E-L of these substrates were twice those of E-H. At equilibrium, the degrees of hydrolysis of CMC by E-H and E-L reached $9.78 \%$ and $9 \cdot 54 \%$, respectively. Avicel, filter paper, swollen celluloses, cellobiose, curdlan ( $\beta$-1,3-linkage), laminarin $(\beta-1,3 ; 1,6$-linkage) and NPG were practically unhydrolysable by either enzyme. This substrate specificity is 
Table 2. Substrate specificity of CMCases

Assays were performed at $30^{\circ} \mathrm{C}$ in $0.1 \mathrm{M}$-glycine $/ \mathrm{NaOH}$ buffer (pH 9.5) with $0.86 \mu \mathrm{g} \mathrm{E}-\mathrm{H}$ or with $0.63 \mu \mathrm{g} \mathrm{E}-\mathrm{L}$ under the standard reaction conditions. Each value is the mean of three determinations, and the activity of E-H against $\mathrm{CMC}$ was taken as $100 \%$.

\begin{tabular}{|c|c|c|c|c|}
\hline \multirow{2}{*}{$\begin{array}{c}\text { Substrate } \\
(1 \%)\end{array}$} & \multicolumn{2}{|c|}{ E-H activity } & \multicolumn{2}{|c|}{ E-L activity } \\
\hline & $\mathbf{U} \mathbf{m g}^{-1}$ & Rel. act. (\%) & $\mathrm{U} \mathrm{mg}^{-1}$ & Rel. act. (\%) \\
\hline CMC & $23 \cdot 5$ & 100 & 43.8 & 186 \\
\hline Avicel & $\operatorname{tr}$ & tr & tr & $\mathbf{t r}$ \\
\hline Filter paper & $\mathbf{t r}$ & tr & tr & tr \\
\hline $\mathrm{H}_{3} \mathrm{PO}_{4}$-swollen cellulose & tr & tr & tr & tr \\
\hline $\mathrm{NaOH}$-swollen cellulose & $\operatorname{tr}$ & tr & $\operatorname{tr}$ & tr \\
\hline Lichenan & 19.7 & 84 & 42.5 & 181 \\
\hline Curdlan & $\mathbf{0}$ & 0 & $\mathbf{0}$ & 0 \\
\hline Laminarin & $\mathbf{0}$ & 0 & 0 & 0 \\
\hline Cellobiose & 0 & 0 & 0 & 0 \\
\hline $\mathrm{NPC}^{*}$ at pH 9.5 & $0 \cdot 3$ & $1 \cdot 3$ & 0.6 & $2 \cdot 6$ \\
\hline at $\mathrm{pH} 7.0$ & 0.8 & $3 \cdot 4$ & $1 \cdot 4$ & $6 \cdot 0$ \\
\hline $\mathrm{NPG}^{*}$ at $\mathrm{pH} 9.5$ & 0 & 0 & 0 & 0 \\
\hline at $\mathrm{pH} 7.0$ & 0 & 0 & 0 & 0 \\
\hline
\end{tabular}

tr, Very low but not negligible activity $\left(<1 \cdot 1 \mathrm{U} \mathrm{mg}^{-1}\right)$.

* Assays were performed with $4 \mu \mathrm{mol}$ substrate in $0.5 \mathrm{ml} 0.1 \mathrm{M}$-glycine/ $/ \mathrm{NaOH}$ buffer $(\mathrm{pH} 9.5)$ or $0.1 \mathrm{M}$ phosphate buffer (pH 7.0), with $0.86 \mu \mathrm{g} \mathrm{E-H} \mathrm{or} 0.63 \mu \mathrm{g} \mathrm{E-L} \mathrm{as} \mathrm{enzyme.}$

consistent with the classification of the Bacillus enzymes as $\beta$-1,4-endoglucanases. Slight, but not negligible, activity against NPC was observed with either enzyme. The maximum activities of the two enzymes toward NPC were both observed at $\mathrm{pH} 7.0$ in $0.1 \mathrm{M}$-phosphate buffer, rather than at alkaline $\mathrm{pH}$. The double-reciprocal plots against NPC yielded apparent $K_{\mathrm{m}}$ values of $0.26 \mathrm{~mm}$ with a $V$ of $1.14 \mathrm{U}(\mathrm{mg} \text { protein })^{-1}$ at $\mathrm{pH} 7.0$, and $1.1 \mathrm{~mm}$ with a $V$ of $0.54 \mathrm{U}$ (mg protein $)^{-1}$ at $\mathrm{pH} 9.5$ for $\mathrm{E}$ $\mathrm{H}$; and, for E-L, $K_{\mathrm{m}}$ values of $0.27 \mathrm{~mm}$ with $V$ of $1.52 \mathrm{U}$ (mg protein) $)^{-1}$ at $\mathrm{pH} 7.0$, and $1.0 \mathrm{mM}$ with a $V$ of $0.83 \mathrm{U}$ (mg protein $)^{-1}$ at $\mathrm{pH} 9 \cdot 5$.

The actions of E-H and E-L on cello-oligosaccharides (G2 through G6) were examined after completion of the reactions, reached after $12 \mathrm{~h}$ at $30^{\circ} \mathrm{C}$ in $50 \mathrm{mM}$ pyrophosphate buffer (pH 9.0). E-H and E-L were alike, in that they acted on $\mathrm{G} 3$ through $\mathrm{G} 6$, yielding $\mathrm{G} 2$ and $\mathrm{G} 1$ as the major products of the hydrolysis. Glucose (G1) was not found as a product of the complete reaction of cellobiose (G2) with these enzymes, indicating again that there was no $\beta$-1,4-glucosidase (cellobiase) activity in the preparations.

\section{Effects of surfactants and chelating agents}

The effects on the activities of E-H and E-L of various surfactants and chelating agents used in laundry detergents were examined at $40^{\circ} \mathrm{C}$ and $\mathrm{pH} 9.5$ in $0.1 \mathrm{M}$ glycine/ $\mathrm{NaOH}$ buffer. Neither enzyme was inhibited at all by alkyl sulphate, $\alpha$-carboxymethyl alkyl sulphate, $\alpha$-olefin sulphonate, polyoxyethylene alkyl sulphate, polyoxyethylene alkyl ether, secondary alkyl sulphonate, sodium laurate (soap), sodium tripolyphosphate, zeolite $4 \mathrm{~A}$ or sodium citrate, each added at a final concentration of $0.05 \%(\mathrm{w} / \mathrm{v})$. EDTA and EGTA, each added at $1 \mathrm{mM}$, slightly inhibited the activities of both enzymes (by about $10 \%$ in each case).

\section{Discussion}

The genus Bacillus represents a group of microorganisms that produce extracellular enzymes of industrial importance (Fogarty et al., 1974; Priest, 1977; Sippola \& Mäntsälä, 1981; Zemek et al., 1981). They are also known for their ability to produce cellulolytic enzymes (Tewari \& Chahal, 1977; Horikoshi et al., 1984; Lobson \& Chambliss, 1984; Dhillon et al., 1985; Chan \& Au, 1987; Kawai et al., 1988; Ito et al., 1989; Shikata et al., 1990), but relatively few attempts have been made to purify and characterize the cellulases that they produce. An alkaline CMCase was purified and characterized to a limited extent by Fukumori et al. (1985), who used the alkalophilic Bacillus sp. no. 1139. Okoshi et al. (1990) purified two alkaline CMCases and one neutral enzyme from the neutrophilic Bacillus sp. KSM-522, and Au \& Chan (1987) isolated one neutral CMCase as the major component from a culture of Bacillus subtilis AU-1.

In this study, alkaline CMCases, E-H and E-L, were purified to homogeneity with high yield from cultures of the alkalophilic Bacillus sp. KSM-635. The use of a crude preparation of the Bacillus sp. KSM-635 cellulase was 
extended by us to inclusion in laundry detergents (Ito $e t$ al., 1989). The purified CMCases, E-H and E-L, are obviously alkaline enzymes with $\mathrm{pH}$ optima at $\mathrm{pH} 9.5$, and they are very stable to incubation at $\mathrm{pH} \mathrm{6-11}$ and against various detergents and chelating agents of laundry detergents. These characteristics of the enzymes make them most suitable for use as effective laundry detergent additives. E-H and E-L contained glucosamine (presumably $N$-acetylglucosamine). There are some reports concerning the physiological function of carbohydrate moieties of glycoproteins (Olden et al., 1982). For example, the carbohydrate moiety of glucoamylase from a strain of Flavobacterium sp. (Takegawa et al., 1988) has been shown to contribute to the high stability of the enzyme against temperature and $\mathrm{pH}$, and to protect it from proteolytic degradation. Protection against proteolytic degradation afforded by the carbohydrate moiety was also reported by Bernard et al. (1983) who studied bovine pancreatic ribonucleases $\mathrm{A}$ and $\mathrm{B}$. Such carbohydrate effects could be applicable to the CMCases from Bacillus sp. KSM-635, which are relatively stable against surfactants and chelating agents.

The purified preparations of E-H and E-L both hydrolysed only CMC and lichenan and did not hydrolyse crystalline celluloses, curdlan and laminarin. Hence, it is probably more appropriate to refer to these enzymes as endo-1,4- $\beta$-glucanases rather than as cellulases. In fact, E-H and E-L rapidly decreased the viscosity of solutions of CMC (data not shown). E-H appears to exist as an aggregate of four identical CMCase subunits with a molecular mass of $130 \mathrm{kDa}$. We have cloned the gene that encodes a Bacillus sp. KSM635 CMCase into Escherichia coli HB101, using pBR322 (Ozaki et al., 1990). There is an open reading frame of $2823 \mathrm{bp}$, which encodes 941 amino acid residues that give a calculated molecular mass of $104626 \mathrm{Da}$. The molecular mass of the plasmid-encoded CMCase is very close to that of E-L, as estimated both by gel filtration on Bio-Gel A-1.5m (100 kDa) and by SDS-PAGE $(103 \mathrm{kDa})$. E-H and E-L, with molecular masses of $130 \mathrm{kDa}$ and $103 \mathrm{kDa}$, are distinguishable from each other with respect to rates of hydrolysis of $\mathrm{CMC}$, lichenan and NPC, but showed essentially the same $\mathrm{pH}-$ activity, $\mathrm{pH}$-stability, temperature-activity and temperature-stability profiles, and their activities were reduced to almost the same extents by various inhibitors and inorganic ions. A possible explanation for the occurrence of these isoenzymes is that they are encoded by different genes. However, as glycoproteins frequently give erroneous molecular mass values when these are estimated by commonly used methods, the reason for the observed discrepancy in molecular masses is not clear.

Microbial extracellular enzymes are generally known to require $\mathrm{Ca}^{2+}$ and some divalent cations for activity and stabilization. $\mathrm{Co}^{2+}$, rather than $\mathrm{Ca}^{2+}$, seemed to stimulate the activity of E-H and E-L. The stimulation by $\mathrm{Co}^{2+}$ of cellulase activity is very unusual among extracellular enzymes and has been reported only for CMCases of Bacillus subtilis AU-1 (Au \& Chan, 1987) and Bacillus sp. KSM-522 (Okoshi et al., 1990). Protection by high concentrations of $\mathrm{Na}^{+}$and $\mathrm{K}^{+}$from thermal inactivation of E-H and E-L cannot readily be explained, but it could arise from some interactions of the cations with free carboxyl groups of some amino acid residues in the CMCase molecules, or from changes in the gross conformation of the enzymes. Both enzymes were strongly inhibited by $\mathrm{Hg}^{2+}$, and such inhibition has been noted with many cellulases, including that of Bacillus $\mathrm{sp}$. no. 1139 (Fukumori et al., 1985). Heavy metal ions are generally thought to inactivate enzymes by forming covalent salts with cysteine moieties in the enzyme molecule. However, amino acid analysis did not detect cysteine in the CMCase proteins of Bacillus sp. KSM-635 (data not shown). Since the genetic analysis of the cellulase genes of Bacillus sp. no. 1139 (Fukumori et al., 1986) and Bacillus sp. KSM-635 (Ozaki et al., 1990) has also shown that these CMCases are devoid of free thiol groups and disulphide linkages, interaction with thiol groups can be ruled out in these cases. The inhibition by $\mathrm{Hg}^{2+}$ could arise from the interaction with tryptophan residues at the active site of the CMCase molecules, as suggested by Eriksson \& Pettersson (1968) and Hurst $e t$ al. (1977). In fact, E-H and E-L have a shoulder absorption at $290 \mathrm{~nm}$, which may be due to tryptophan residues (Clarke, 1987), and the activities of E-H and E$\mathrm{L}$ were completely inhibited by $\mathrm{N}$-bromosuccinimide at concentrations below $10 \mu \mathrm{M}$.

The authors thank Dr K. Horikoshi of the Riken Institute, Saitama, Japan, for helpful discussions and for reading the manuscript.

\section{References}

AU, K.-S. \& Chan, K.-Y. (1987). Purification and properties of the endo-1,4- $\beta$-glucanase from Bacillus subtilis. Journal of General Microbiology 133, 2155-2162.

BÉGUIN, P. (1983). Detection of cellulase activity in polyacrylamide gels using Congo red-stained agar replicas. Analytical Biochemistry 131, 333-336.

Beldman, G., Serle-Vanleeuwen, F. M., Rombout, F. M. \& Woragen, G. J. (1985). The cellulase of Trichoderma viride. Purification, characterization and comparison of all detectable endoglucanases, exoglucanases and $\beta$-glucosidases. European Journal of Biochemistry 146, 301-308.

Berghem, L. E. R., Pettersson, L. G. \& Axio-Fredriksson, U. B. (1976). The mechanism of enzymatic cellulose degradation. Purification and some properties of two different 1,4- $\beta$-glucan glucanohydrolases from Trichoderma viride. European Journal of Biochemistry 61, $620-630$.

Bernard, B. A., Newton, S. A. \& Olden, K. (1983). Effect of size and location of oligosaccharide chain on protease degradation of bovine pancreatic ribonuclease. Journal of Biological Chemistry 258, 1219812202. 
when large cell numbers needed for biochemical localization are not available.

Although malate dehydrogenase (decarboxylating) activity was detectable in the whole cell homogenate, the enzyme was not organelle-associated in P. multivesiculatum. Non-sedimentable (i.e. soluble) malate dehydrogenase (decarboxylating) has also been detected in the rumen ciliates Dasytricha ruminantium, Isotricha prostoma and I. intestinalis (Yarlett et al., 1981, 1983a). However, this particular activity within the trichomonad flagellates (Müller, 1980), mixed rumen ophryoscolecid ciliates (Snyers et al., 1982) and the rumen fungus Neocallimastix patriciarum (Yarlett et al., 1986) is sedimentable. Further studies on the occurrence and distribution of this enzyme in other rumen ciliates are therefore warranted, as there would appear to be species differences in the complement of hydrogenosomal enzymes.

This research was supported by grant AG 34/60 from the Agriculture and Food Research Council.

\section{References}

Beaufay, H. \& Amar-Costesec, A. (1976). Cell fractionation techniques. Methods in Membrane Biology 6, 1-100.

Bradbury, S. \& Steward, V. W. (1964). A note on the electron staining of diformazan deposits in tissue sections. Journal of the Royal Microscopical Society 83, 467-470.

BRADFORD, M. M. (1976). A rapid and sensitive method for the quantitation of microgram quantities of protein utilizing the principle of protein-dye binding. Analytical Biochemistry 72, . 248-254.

Coleman, G. S. (1978). Rumen entodiniomorphid protozoa. In Methods of Cultivating Parasites In Vitro, pp. 39-54. Edited by A. E. R. Taylor \& J. R. Baker. London \& New York: Academic Press.

Contantinescu, E. \& Dragos, N. (1984). Unele aspecte de structura electronmicroscopica a infuzorilor ruminali de la ovine. Buletinul Institutului Agronomic Cluj-Napoca, Seria Zootehnie si Medicina Veterinara 38, 57-60.

DeLfosse-DebusCHER, J. (1977). Ultrastructure de l'endoplasme des ophryoscolecides. Cellule 72, 77-90.

Ellis, J. E., Lloyd, D. \& Williams, A. G. (1989a). Protozoal contribution to ruminal oxygen utilization. In Biochemistry and Molecular Biology of "Anaerobic" Protozoa, pp. 32-41. Edited by D. Lloyd, G. H. Coombs \& T. Paget. Chur, Switzerland: Harwood Academic Publishers.

Ellis, J. E., Williams, A. G. \& Lloyd, D. (1989b). Oxygen consumption by ruminal microorganisms: protozoal and bacterial contributions. Applied and Environmental Microbiology 55, 25832587.

DI FANChiotti, L. A. C., Jones, G. R. W. \& Bradbury, S. (1971). The intramitochondrial localisation of succinate-yellow tetrazolium reductase with the electron microscope. Histochemie 27, 28-35.

HANKER, J. S. (1975). Oxidoreductases. In Electron Microscopy of Enzymes, vol. 4, pp. 1-139. Edited by M. A. Hayat. New York: Van Nostrand Reinhold.
Hillman, K., Lloyd, D., Scott, R. I. \& Williams, A. G. (1985). The effects of oxygen on hydrogen production by rumen holotrich protozoa, as determined by membrane-inlet mass spectrometry. In Microbial Gas Metabolism: Mechanistic, Metabolic and Biotechnological Aspects, pp. 271-277. Edited by R. K. Poole \& C. S. Dow. London \& New York: Academic Press.

LiNDMARK, D. G. \& MüllER, M. (1973). Hydrogenosome, a cytoplasmic organelle of the anaerobic flagellate Tritrichomonas foetus and its role in pyruvate metabolism. Journal of Biological Chemistry 248, 7724-7728.

LINDMARK, D. G. \& MÜlLeR, M. (1974). Biochemical cytology of trichomonad flagellates. II. Subcellular distribution of oxidoreductases and hydrolases in Monoceromonas sp. Journal of Protozoology 21, 374-378.

Lloyd, D., Hillman, K., Yarlett, N. \& Williams, A. G. (1989). Hydrogen production by rumen holotrich protozoa: effects of oxygen and implications for metabolic control by in situ conditions. Journal of Protozoology 36, 205-213.

Lockwood, B. C., Coombs, G. H. \& Williams, A. G. (1988). Proteinase activity in rumen ciliate protozoa. Journal of General Microbiology 134, 2605-2614.

MüLLER, M. (1980). The hydrogenosome. In The Eukaryotic Microbial Cell, pp. 127-142. Edited by G. W. Gooday, D. Lloyd \& A. P. J. Trinci. Cambridge: Cambridge University Press.

MÜLLER, M. (1988). Energy metabolism of protozoa without mitochondria. Annual Review of Microbiology 42, 465-488.

Snyers, L., Hellings, P., Bovy-Kesler, C. \& Thines-Sempoux, D. (1982). Occurrence of hydrogenosomes in the rumen ciliates Ophryoscolecidae. FEBS Letters 137, 35-39.

STEINBÜCHEL, A. \& MǗLLER, M. (1986). Anaerobic pyruvate metabolism of Tritrichomonas foetus and Trichomonas vaginalis hydrogenosomes. Molecular and Biochemical Parasitology 20, 57-65.

THORNELEY, R. N. F. (1974). A convenient electrochemical preparation of reduced methylviologen and kinetic study of the reaction with oxygen using an anaerobic stopped-flow apparatus. Biochimica et Biophysica Acta 333, 487-496.

Williams, A. G. (1986). Rumen holotrich ciliate protozoa. Microbiological Reviews 50, 25-49.

Williams, A. G. \& Coleman, G. S. (1988). The rumen protozoa. In The Rumen Microbial Ecosystem, pp. 77-128. Edited by P. N. Hobson. London \& New York: Elsevier Applied Science.

Williams, A. G. \& Ellis, A. B. (1985). Subcellular distribution of glycoside hydrolase and polysaccharide depolymerase enzymes in the rumen entodiniomorphid ciliate Polyplastron multivesiculatum. Current Microbiology 12, 175-182.

YARLETT, N., LLOYD, D. \& WILLIAMS, A. G. (1982). Respiration of the rumen ciliate Dasytricha ruminantium Schuberg. Biochemical Journal 206, 259-266.

Yarlett, N., Coleman, G. S., Williams, A. G. \& Lloyd, D. (1984). Hydrogenosomes in known species of rumen entodiniomorphid protozoa. FEMS Microbiology Letters 21, 15-19.

Yarlett, N., HanN, A. C., Lloyd, D. \& Williams, A. G. (1981). Hydrogenosomes in the rumen protozoon Dasytricha ruminantium Schuberg. Biochemical Journal 200, 365-372.

Yarlett, N., Hann, A. C., Lloyd, D. \& Williams, A. G. (1983a). Hydrogenosomes in a mixed isolate of Isotricha prostoma and Isotricha intestinalis from ovine rumen contents. Comparative Biochemistry and Physiology 74B, 357-364.

YARLETT, N., ORPIN, C. G., MUNN, E. A., YarletT, N. \& GREENWOOD, C. A. (1986). Hydrogenosomes in the rumen fungus Neocallimastix patriciarum. Biochemical Journal 236, 729-739.

Yarlett, N., Scott, R. I., Williams, A. G. \& Lloyd, D. (1983b). A note on the effects of oxygen on hydrogen production by the rumen protozoon Dasytricha ruminantium Schuberg. Journal of Applied Bacteriology 55, 359-361.

ZWART, K. B., Goosen, N. K., VAN SchiJndel, M. W., Broers, C. A. M., Stumm, C. K. \& Vogels, G. D. (1988). Cytochemical localization of hydrogenase activity in the anaerobic protozoa Trichomonas vaginalis, Plagiopyla nasuta and Trimyema compressum. Journal of General Microbiology 134, 2165-2170. 